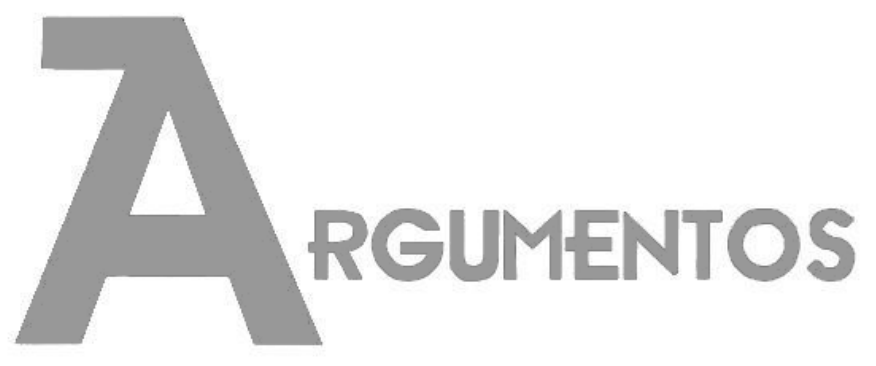

Vol. 17, n. 2, jul./dez. 2020 ISSN: 2527-2551 (online)

\title{
Memória olímpica como legado? A Fundação Casa de Rui Barbosa e seu projeto institucional de preservação da memória das Olimpíadas Rio $2016^{1}$
}

\author{
Bernardo Buarque de Hollanda ${ }^{2}$ \\ Vivian Luiz Fonseca ${ }^{3}$
}

Recebido em: 26/05/2020

Aprovado em: 01/06/2020

\begin{abstract}
Resumo: O presente artigo examina o caso de uma iniciativa institucional voltada à preservação da memória dos Jogos Olímpicos de Verão Rio 2016. Procura-se mostrar de que maneira, em paralelo às ações governamentais e à performance dos atletas durante o torneio realizado no Rio de Janeiro, houve um notável investimento de parte da instituição no sentido de salvaguardar o registro dos acontecimentos desse até então inédito megaevento esportivo no Brasil, ocorrido pela primeira vez da sua história em uma cidade da América do Sul. Em que pese uma série de críticas e questionamentos feitos à organização das Olimpíadas por parte da opinião pública, e mesmo de parcelas da Academia, salientam-se aqui os esforços de uma rede de pesquisadores com vistas a construir e a fixar uma memória coletiva em torno do evento. Para destacar esse aspecto, incluído na chave nativa de um "legado", mobilizaremos o exemplo paradigmático da Fundação Casa de Rui Barbosa, que, em conjunto com o FGV CPDOC, desenvolveu um amplo programa de acompanhamento e cobertura dos Jogos durante o ano de sua realização. Com efeito, abordaremos de início o conceito de memória e, em particular, do que denominamos "memória esportiva". Na sequência, amparados em fontes primárias, trataremos da concepção de processos e ações dedicadas ao registro do megaevento esportivo
\end{abstract}

\footnotetext{
${ }^{1}$ O presente trabalho foi realizado com apoio da Coordenação de Aperfeiçoamento de Pessoal de Nível Superior - Brasil (Capes) - Código de Financiamento 001.

2 Doutor em História Social da Cultura (PUC-Rio). Professor-adjunto da FGV CPDOC e bolsista de produtividade em pesquisa (PQ) do CNPq. Professor do Programa de Pós-Graduação em História, Política e Bens Culturais (FGV CPDOC). E-mail: bernardobuarque@gmail.com. Registro ORCID: https://orcid.org/0000-0001-7781-4684.

${ }^{3}$ Doutora em História, Política e Bens Culturais (FGV). Pesquisadora e Coordenadora do Programa de História Oral do FGV CPDOC e Professora Adjunta do Departamento de História da UERJ, Professora dos Programas de Pós-Graduação em História, Política e Bens Culturais (FGV CPDOC) e do Programa de PósGraduação de Mestrado Profissional em Ensino de História (Prof. História/UERJ). Pesquisadora associada ao INCT Proprietas. E-mail: vivianluizfonseca@gmail.com. Registro ORCID: https://orcid.org/0000-00020943-9752.
} 
Dossiê | Memória olímpica como legado? A Fundação Casa de Rui Barbosa e seu projeto institucional de preservação da memória das Olimpíadas Rio 2016 (HOLLANDA, Bernardo Buarque de; FONSECA, Vivian Luiz)

na cidade, por parte da FCRB. Em seguida, exploraremos um de seus eixos mais importantes, a História Oral, implementado em parceria com o FGV CPDOC, na seleção de relatos dos atores envolvidos com o torneio no contexto de sua realização. Por fim, daremos a conhecer a exposição "Rio de Janeiro - cidade esportiva, cidade olímpica", ocorrida nas dependências da Fundação, com base em seu rico acervo documental de jornais e revistas ilustradas, de modo a salientar os vínculos entre a história republicana da instituição, as competições esportivas no país e a construção de um lugar de memória olímpica para a cidade em questão.

Palavras-chave: Jogos Olímpicos Rio 2016; Memória; Esportes; História Oral; Cidade.

\section{¿Memoria olímpica como legado? \\ Fundação Casa de Rui Barbosa y su proyecto institucional para preservar la memoria de los Juegos Olímpicos de Río 2016}

Resumen: Este artículo examina el caso de una iniciativa institucional dirigida a preservar la memoria de los Juegos Olímpicos de Verano de Río 2016. Busca mostrar cómo, en paralelo con las acciones del gobierno y el desempeño de los atletas durante el torneo celebrado en Río de Janeiro, hubo una notable inversión por parte de la institución para salvaguardar el registro de los eventos de ese megaevento deportivo hasta ahora sin precedentes en Brasil, que ocurrió por primera vez en su historia en una ciudad de América del Sur. A pesar de una serie de críticas y preguntas hechas Para la organización de los Juegos Olímpicos por la opinión pública, e incluso de partes de la Academia, se destacan los esfuerzos de una red de investigadores con miras a construir y asegurar una memoria colectiva en torno al evento. Para resaltar este aspecto, incluido en la clave nativa de un "legado", movilizaremos el ejemplo paradigmático de la Fundación Casa de Rui Barbosa, que, junto con FGV CPDOC, desarrolló un amplio programa para monitorear y cubrir los Juegos durante el año de su realización. De hecho, comenzaremos con el concepto de memoria y, en particular, de lo que llamamos "memoria deportiva". Luego, con el apoyo de fuentes primarias, abordaremos el diseño de procesos y acciones dedicadas al registro del megaevento deportivo en la ciudad, por parte de la FCRB. Luego, exploraremos uno de sus ejes más importantes, Historia Oral, implementado en colaboración con FGV CPDOC, en la selección de informes de los actores involucrados en el torneo en el contexto de su realización. Finalmente, presentaremos la exposición "Río de Janeiro - ciudad deportiva, ciudad olímpica", que tuvo lugar en las instalaciones de la Fundación, basada en su rica colección documental de periódicos y revistas ilustradas, para resaltar los vínculos entre la historia republicana de institución, competiciones deportivas en el país y la construcción de un lugar de memoria olímpica para la ciudad en cuestión.

Palabras clave: Juegos Olímpicos de Río 2016; Memoria; Deportes; Historia oral; Ciudad.

\section{Olympic memory as a legacy? \\ Fundação Casa de Rui Barbosa and its institutional project to preserve the memory of the Rio 2016 Olympics}

Abstract: This article examines the case of an institutional initiative thats aimed to preserv the
memory of the Rio 2016 Summer Olympics. It seeks to show how, in parallel with government
actions and the performance of athletes during the tournament held in Rio de Janeiro, there
was a notable investment on the part of the institution in order to safeguard the record of the
events of that unprecedented sports mega-event in Brazil, which occurred for the first time in
its history in a city in South America. Despite a series of criticisms and questions made to the
organization of the Olympics by public opinion, and even from parts of the Academy, the efforts
of a network of researchers with a view to building and securing a collective memory around
the event are highlighted. To highlight this aspect, included in the native key of a "legacy", we
will mobilize the paradigmatic example of the Casa de Rui Barbosa Foundation, which, together 
Dossiê | Memória olímpica como legado? A Fundação Casa de Rui Barbosa e seu projeto institucional de preservação da memória das Olimpíadas Rio 2016 (HOLLANDA, Bernardo Buarque de; FONSECA, Vivian Luiz)

with FGV CPDOC, developed a broad program for monitoring and covering the Games during the year of its realization. In fact, we will start with the concept of memory and, in particular, of what we call "sports memory". Then, supported by primary sources, we will deal with the design of processes and actions dedicated to the registration of the sports mega-event in the city, by the FCRB. Then, we will explore one of its most important axes, Oral History, implemented in partnership with FGV CPDOC, in the selection of reports of the actors involved with the tournament in the context of its realization. Finally, we will present the exhibition "Rio de Janeiro - sports city, Olympic city", which took place on the Foundation's premises, based on its rich documentary collection of illustrated newspapers and magazines, in order to highlight the links between the republican history of institution, sports competitions in the country and the construction of a place of Olympic memory for the city in question.

Keywords: Rio 2016 Olympic Games; Memory; Sports; Oral History, City.

\section{Introdução}

Quatro anos passaram-se desde o encerramento da 31a edição dos Jogos Olímpicos de Verão Rio 2016, realizados na cidade do Rio de Janeiro durante o mês de agosto daquele ano, mais precisamente entre os dias 05 e 21 . 0 torneio, seguido imediatamente pelos Jogos Paralímpicos, entre 7 e 18 de setembro, foi o coroamento da chamada "década esportiva" (SPAGGIARI; MACHADO; GIGLIO, 2016) do Brasil, quando completaram-se 10 anos de competições de grande escala acontecidas no país. Como se sabe, seu início remonta a 2007, com a realização dos Jogos Pan-Americanos do Rio de Janeiro, ano também do anúncio do Brasil como país-sede da Copa do Mundo da FIFA de 2014, e se distende até as referidas Olimpíadas de 2016, também no Rio.

O "decênio", entretanto, não suscitou à primeira vista muitas comemorações, em particular no que tange ao Jogos Olímpicos. No último quadriênio, uma série de reportagens e matérias jornalísticas tem salientado problemas referentes à manutenção e à utilização de equipamentos esportivos, vistos em princípio como o mais importante "legado" - categoria êmica, aqui reproduzida - do evento para a cidade brasileira. Outros benefícios tangíveis costumaram ser mencionados e prometidos, mas estão hoje fora de cogitação em termos de sua concretização. Entre eles, salvo melhorias pontuais, citem-se as supostas vantagens urbanísticas e de transportes deixadas à cidade-sede responsável por organizar e realizar as competições, que mobilizaram milhares de atletas e centenas de delegações, representantes de mais de 200 países, para um total de quase 40 modalidades esportivas.

Antes de 2016, a mobilidade urbana, por exemplo, foi muito acentuada. Tratavase de uma conquista para o futuro da cidade, quando do anúncio do Rio de Janeiro na 
Dossiê | Memória olímpica como legado? A Fundação Casa de Rui Barbosa e seu projeto institucional de preservação da memória das Olimpíadas Rio 2016 (HOLLANDA, Bernardo Buarque de; FONSECA, Vivian Luiz)

condição de anfitriã do megaevento. Falou-se ainda nas benesses advindas da ativação da rede hoteleira, nas oportunidades do turismo, no fomento ao setor de serviços e no incremento ao mercado imobiliário. Lembre-se também o investimento financeiro e infraestrutural na criação de novos museus para a cidade e na revitalização da zona portuária, região central e histórica, havia muito tempo sem investimentos públicos adequados.

Ademais, a visibilidade outorgada pela competição, chancelada pelo Comitê Olímpico Internacional, foi vista igualmente como um trunfo para a inserção do Rio na condição de "cidade global", espécie de vitrine para o mundo durante quase três semanas de disputas olímpicas. Computem-se, para tanto, os milhões de telespectadores e os milhares de turistas, estrangeiros e brasileiros, que se deslocaram para seguir o evento quadrienal, com potenciais desdobramentos positivos nos anos seguintes.

Com efeito, sabe-se, na atualidade que boa parte da expectativa de vantagens do evento frustrou-se com a passagem do tempo. Embora o evento em si tenha acontecido sem maiores transtornos ou comprometimentos de organização - embora não sem tensão e alguns incidentes reportados pelos meios de comunicação -, relatam-se em sua esteira as dificuldades de implementação do cronograma de obras, a crise do modelo organizacional adotado pelo $\mathrm{COI}$ - com mais deveres que direitos à cidade-sede - como também as consequências nefastas da crise econômico-política por que passou o país desde meados dos anos 2010.

Em adendo, diversas suspeições de corrupção ou desvios foram imputadas a entes envolvidos em distintas situações, sejam órgãos da Prefeitura da cidade, sejam figuras do Comitê Olímpico Brasileiro (COB) - evoque-se a prisão de seu presidente Arthur Nuzman - seja mesmo a gestão do COI.

O ceticismo quanto à positividade de um legado - esportivo, social e urbano - é na atualidade bastante generalizado, com uma sensação negativa mais ampla quando se faz um balanço retrospectivo do significado da efeméride olímpica para o Brasil como um todo. Sem deixar de concordar com a maior parte das análises críticas acerca das mazelas das Olimpíadas 2016, sendo provavelmente a mais substantiva delas aquela 
Dossiê | Memória olímpica como legado? A Fundação Casa de Rui Barbosa e seu projeto institucional de preservação da memória das Olimpíadas Rio 2016 (HOLLANDA, Bernardo Buarque de; FONSECA, Vivian Luiz)

formulada pelo antropólogo Arlei Damo $(2013)^{4}$, entendemos que uma avaliação do evento em seu conjunto pode contemplar, em contrapartida, dimensões e aspectos ainda pouco frisados ou estudados no que tange ao seu propalado "legado".

Nesse sentido, o presente artigo pretende contribuir com um debate em torno de exemplos dos processos de construção de uma memória coletiva para os Jogos Olímpicos Rio 2016, com base na reconstituição de determinadas iniciativas de parte de instituições, a fim de preservar e conservar, em termos materiais e simbólicos, a realização do evento. Isto afigura-se vantajoso inclusive do ponto de vista de uma agenda de pesquisas e de investigações na área de história e sociologia dos esportes, cujo crescimento e afirmação no Brasil, como se sabe, foi tardio, mas que se consolidou nos últimos anos, junto aos próprios fenômenos que estuda.

Para tal finalidade, o texto estrutura-se em quatro partes. A primeira dedica-se a refletir sobre a polissemia do conceito de memória, particularmente de "memória esportiva", a partir de trabalhos de filósofos, historiadores e cientistas sociais dedicados a pensar em processos rememorativos que tenham por fundo atividades de esportes, em geral, e de modalidades olímpicas, em particular. Sustenta-se que esse reconhecimento mais amplo da esfera dos esportes como um vetor identitário moderno e contemporâneo foi o fator que permitiu que agentes e entes públicos pudessem investir nesse setor para fixar e legar fontes para a construção da memória olímpica de 2016.

A segunda seção deste artigo debruça-se sobre ações e processos de um amplo projeto de pesquisa desenvolvido pela Fundação Casa de Rui Barbosa, no Rio de Janeiro, instituição à época vinculada ao Ministério da Cultura (MinC), instada pelas autoridades governamentais a cooperar nessa frente de atuação na salvaguarda da memória dos Jogos Rio 2016. Procura-se mostrar o delineamento de uma frente de atividades coletivas que, ao longo do ano de 2016, tencionou cobrir uma gama de aspectos relacionados ao megaevento esportivo, de modo a criar registros - sonoros, visuais, virtuais, impressos - capazes de legar uma memória da efeméride extraordinária que teve a cidade do Rio de Janeiro como palco e receptáculo internacional. O projeto em

\footnotetext{
${ }^{4}$ Os geógrafos Raquel Rolnik (FAU/USP) e Gilmar Mascarenhas (Geografia/UERJ), e o urbanista Carlos Vainer (IPPUR/UFRJ) foram alguns dos autores que desenvolveram uma perspectiva crítica a propósito das injunções político-econômicas dos Jogos Rio 2016.
} 
Dossiê | Memória olímpica como legado? A Fundação Casa de Rui Barbosa e seu projeto institucional de preservação da memória das Olimpíadas Rio 2016 (HOLLANDA, Bernardo Buarque de; FONSECA, Vivian Luiz)

questão foi desenvolvido a partir de uma parceria com o Centro de Pesquisa e Documentação em História Contemporânea do Brasil, da Fundação Getulio Vargas (FGV CPDOC).

A terceira parte reconstitui as etapas do subprojeto específico da Casa de Rui Barbosa em conjunto com o FGV CPDOC relativo à criação de um acervo de entrevistas de história oral com atores envolvidos na organização e realização da Rio 2016. Esse subprojeto trata-se de um recorte da pesquisa "Memória das Olimpíadas: projetos e ações" que, em linhas gerais, se propôs a criar um repositório digital sobre a experiência olímpica brasileira. Destaque-se que o CPDOC é reconhecido pela sua expertise nessa metodologia, o que contribuiu para a produção de um conjunto de depoimentos com uma gama de atores relacionados às Olimpíadas no Brasil, entre gestores e políticos.

A quarta e última seção lida com outra proposta de conservação memorial do evento no Brasil, também por iniciativa da Casa de Rui Barbosa. Logo após o término dos Jogos Olímpicos, em setembro de 2016, inaugurou-se nas dependências da Fundação a exposição "Rio de Janeiro: cidade esportiva, cidade olímpica", que oferece ao grande público textos e imagens da antiga capital da República, a partir de fontes lastreadas em documentação jornalística (periódicos impressos e revistas ilustradas) depositadas no acervo da instituição. A exposição remete aos primórdios da República no país, à introdução dos esportes modernos na cidade e às primeiras edições das Olimpíadas no século XX, tais como narradas pela imprensa da época.

Isso posto, argumenta-se assim que, ante o envolvimento institucional a seguir demonstrado, a Casa de Rui acaba por funcionar como um "lugar de memória" dos Jogos Olímpicos de 2016, por meio da reprodução de elementos tangíveis e intangíveis que pretendem constituir um espaço de salvaguarda, a dotar um acervo sobre esse acontecimento de escala internacional ocorrido no país há quatro anos atrás para as futuras gerações de pesquisadores e apreciadores do evento.

\section{Das artes da memória à memória dos esportes}

A constituição de uma memória coletiva; as inter-relações desta com a sociedade; as conexões entre escrita e oralidade na tradição ocidental; e a dinâmica de lembrança e esquecimento na história literária, cultural e filosófica da Europa - eis alguns dos 
Dossiê | Memória olímpica como legado? A Fundação Casa de Rui Barbosa e seu projeto institucional de preservação da memória das Olimpíadas Rio 2016 (HOLLANDA, Bernardo Buarque de; FONSECA, Vivian Luiz)

grandes desafios conceituais com que via de regra se deparam os historiadores. 0 conceito de memória é polissêmico e, ao mesmo tempo, de acordo com o filólogo alemão Harald Weinrich, ao citar o retórico latino Plínio, em sua obra monumental Lete: arte e crítica do esquecimento: "nada no ser humano é tão frágil quanto a memória" (2001, p. 219).

O campo das Ciências Sociais contribui com a reflexão levantada pelo antropólogo Gilberto Velho, em seu artigo "Memória, identidade e projeto - uma visão antropológica" (1994). Segundo este autor, a discussão sobre a memória nas últimas décadas situa-se nos quadros de constituição da sociedade ocidental moderna e de conformação do individualismo contemporâneo. Em oposição conceitual à sociedade tradicional, hipoteticamente mais holística e coesa, em que a identidade do indivíduo se encontra subsumida a uma categoria social mais abrangente, a sociedade moderna caracteriza-se pela complexidade das relações sociais, pela heterogeneidade das visões de mundo e pela multiplicidade dos estilos de vida, em que a autonomia do sujeito torna-o menos atrelado a uma identidade coletiva uniforme.

Com a ênfase da sociedade voltada para o indivíduo, o discurso sobre as trajetórias de vida, os perfis individuais e as biografias particulares assumem grande relevância. Ante a fragmentação própria da modernidade, a identidade do indivíduo encontraria na memória um polo unificador das suas múltiplas experiências. O outro polo de unificação, correlato à identidade do indivíduo, estaria contido na noção de projeto, onde a ação individual destina-se a um determinado fim.

A pressuposição tácita dos diferentes estudiosos é o de que há um corte entre tradição e modernidade, a afetar o modo como concebemos e nos relacionamos com a memória. Para Weinrich, as tradições foram esquecidas pela sociedade moderna ocidental, ao passo que, segundo a historiadora Francis Yates (2007), verifica-se desde então um declínio das "artes da memória", na condição de conhecimento hermético e iniciático do Renascimento. As concepções de tempo-espaço, com fundamento sagrado ou pré-moderno, articulam-se, não obstante, a práticas e visões de mundo diluídas na modernidade, mas que continuam latentes em uma sociedade progressivamente secularizada.

A relação entre oralidade e escrita é um dos eixos centrais dessa discussão conceitual e histórica. Sua importância pode ser dimensionada em função do lugar que 
Dossiê | Memória olímpica como legado? A Fundação Casa de Rui Barbosa e seu projeto institucional de preservação da memória das Olimpíadas Rio 2016 (HOLLANDA, Bernardo Buarque de; FONSECA, Vivian Luiz)

ela ocupa na dialética de lembrança e esquecimento. Esta faz-se presente ao longo da história do Ocidente, sendo colocada e recolocada com constância. Chega a impressionar a frequência com que ela aparece problematizada por autores das mais diversas procedências.

O historiador francês Pierre Nora associa o par oralidade/escrita a um esquema de análise sociológica que liga a primeira a sociedades baseadas na memória e a segunda a sociedades centradas na história. Na história ocidental, a passagem de uma ordem tradicional a uma outra moderna é acompanhada por alterações substantivas na relação entre o oral e o escrito. Sob uma perspectiva enciclopédica, que vamos explorar adiante, o medievalista Jacques Le Goff trabalha com a interpolação da memória oral à memória escrita. Esta última expande progressivamente seu alcance, passando por uma posição periférica e secundária a uma posição central com o Renascimento.

A classificação do eminente historiador francês possibilita o entendimento do tipo de memória que orienta a vivência coletiva. A memória étnica, a seu juízo, própria de sociedades sem escrita, constituiria o elo mais elementar da cadeia histórica das sociedades humanas. A identidade dos grupos sociais tem como fundamento os mitos de origem, que, por sua vez, são perpetuados com base em certas práticas de memorização. A narração e a reprodução mnemônica dos primórdios de uma coletividade dependeria, em virtude disso, não só das vicissitudes da memória como de uma espécie de "cantar mítico da tradição" (LEGOFF, 1986, p. 14).

Não obstante, ao contrário de Le Goff, o antropólogo francês Leroi-Gourhan aplica o termo "memória étnica" a todas as coletividades humanas, não apenas a sociedades sem escrita. Este procedimento parece-nos mais adequado, a propósito, pois se desvencilha do espectro do evolucionismo.

O geógrafo norte-americano David Lowenthal, em seu texto "How do we know the past?" (1985), agrega mais um fator a esse debate, ao estipular as relíquias como uma das três vias de acesso ao passado. Ao lado dela, situam-se, como dito acima, a memória e a história, ou a oralidade e a escrita. Uma investigação que almeje uma percepção coerente de eventos pregressos deve procurar ao máximo a combinação entre estas três instâncias, pois elas são complementares. O passado lembrado, o passado registrado e o passado tangível devem ser reciprocamente ligados, variando a incidência de cada um conforme o fato que pretende elucidar. 
Dossiê | Memória olímpica como legado? A Fundação Casa de Rui Barbosa e seu projeto institucional de preservação da memória das Olimpíadas Rio 2016 (HOLLANDA, Bernardo Buarque de; FONSECA, Vivian Luiz)

Desde logo é assumida, porém, a impossibilidade epistemológica de apreensão e de captação do passado em sua totalidade. O passado é multiforme, inabarcável em sua integralidade. As relíquias, como sobrevivência tanto materiais quanto simbólicas do passado no presente, são exemplo concreto de que apenas de maneira fragmentária e residual é possível conhecer o mundo que passou, donde seu caráter construtivo e seletivo.

Além de parciais, as relíquias são vestígios perecíveis, mutáveis e fugidios. Como bens naturais e culturais, elas estão expostas ao desgaste do tempo e à intervenção humana, seja no sentido de preservá-las ou de alterá-las. Mas, por mais passíveis de erosão e de manipulação, uma de suas características é a recorrência e a contínua renovação. As relíquias são ao mesmo tempo incidentais e infindáveis, raras e ubíquas. A todo instante depara-se com elas; o mais das vezes, há uma relíquia em vias de extinção, prestes a sucumbir.

Segundo Walter Benjamin (2018), a modernidade europeia oitocentista inaugurou a era da reprodutibilidade técnica. Embora a preocupação central do pensador alemão fosse com o declínio da aura da obra de arte nos tempos modernos, é possível notar como tal transformação teve impacto em todas as esferas da vida social, cultural e material, e não apenas no universo artístico.

Conquanto únicas e insubstituíveis, as relíquias tornaram-se alvo de expansão em larga escala. Um claro exemplo disto, dado por Lowenthal, encontra-se na indústria do turismo, tal como a conhecemos nos dias atuais. Réplicas, miniaturas e toda sorte de souvenires reproduzem símbolos e cartões-postais das cidades por onde se viaja. Uma parafernália de imagens e objetos é estruturada para oferecer bens de consumo ao turista saturado de informações e de roteiros preestabelecidos.

Junto à reprodução de objetos, pode-se dizer que a imagem ocupa um papel preponderante na sociedade contemporânea. O computador e o universo digital são componentes significativos desse processo exponencial de ampliação das capacidades visuais e virtuais proporcionadas pelo advento das novas tecnologias - tais como a microcomputação e os cabos de fibras óticas - dos anos 1970 em diante (Sevcenko, 2001).

Antes disso, voltando ao historiador francês Jacques Le Goff, no primeiro volume da Enciclopédia Einaudi (1986, p. 40), a década de 1950 já marcara uma revolução na 
Dossiê | Memória olímpica como legado? A Fundação Casa de Rui Barbosa e seu projeto institucional de preservação da memória das Olimpíadas Rio 2016 (HOLLANDA, Bernardo Buarque de; FONSECA, Vivian Luiz)

memória, de que a sua faceta eletrônica atual é o corolário mais espetacular. É, entretanto, nos interstícios desta linguagem revolucionária criada pela informática, que se podem captar as formas constantes e arquetípicas utilizadas pelo ser humano para a conservação de sua memória, de sua história e de suas relíquias.

E o que dizer, no século XXI, da análise da memória com base no complexo poderoso, mas igualmente frágil e fugidio suporte como a informática, a Internet e o mundo virtual como um todo? A ausência de uma linguagem regida pela lógica matricial e a dinâmica constitutiva dos hipertextos aumentam ainda mais a complexidade hodierna do fenômeno digital, com relação à saturação da informação sobre a capacidade exponencial de registrar, de rememorar e de armazenar.

No caso aqui em questão: de que maneira esse debate adentra a seara dos esportes, conjunto de práticas intrinsicamente relacionadas às transformações do mundo moderno-contemporâneo (Elias; Dunning, 2018)?

Assim como se convencionou falar em tempo cronológico e em tempo social, é possível aludir a uma relativa autonomia de um tempo esportivo na contemporaneidade. Um calendário regular e preestabelecido compreende ciclos de campeonatos em multivariadas escalas - comunitária, local, regional, nacional, continental e internacional -, em que as equipes coletivamente, ou os atletas em nível individual, têm de superar a si e aos outros. Ao fim e ao cabo, num sistema em teoria baseado no princípio do mérito, do esforço e do desempenho, elege-se um vencedor ou um campeão.

Nesse contexto, a antropologia social e urbana salienta os esportes modernos como partes constitutivas de um ritual coletivo e de um drama articulados ao meio a que pertencem. De maneira análoga a ritualizações festivas e sagradas, o futebol e outras modalidades esportivas colocam em suspenso os papeis ordinários do cotidiano, e recriam a urdidura de identidades sociais, seja de espectadores seja de atletas. Muitas das vezes, os estádios e os equipamentos esportivos tornam-se microcosmos da nação e os jogos permitem descrições densas, por meio dos quais capta-se a lógica maior que preside as relações em sociedade.

Desde Pierre Bourdieu (1990), convencionou-se dizer que o campo dos esportes é relativamente autônomo, sendo constituído por profissionais, amadores (os torcedores) e especialistas. Estes agentes em disputa pautam sua existência em torno do assim 
Dossiê | Memória olímpica como legado? A Fundação Casa de Rui Barbosa e seu projeto institucional de preservação da memória das Olimpíadas Rio 2016 (HOLLANDA, Bernardo Buarque de; FONSECA, Vivian Luiz)

chamado espaço e "tempo esportivo". Os dias de jogos são a ocasião primordial para a coesão desses indivíduos. Através da regularidade de um calendário temporal cíclico semanal, mensal, anual, quadrienal, etc. -, estes seguidores estabelecem um fio de continuidade com o passado, o que lhes permite comemorar, isto é, em voltar a lembrar de eventos e de fatos - esquecendo-se de outros, por suposto - associados a uma memória afetiva compartilhada em comum.

Se a comemoração - ou seja, o ato de recordar - é passada de geração a geração, os esportes contemporâneos contam ademais com a presença decisiva dos meios de comunicação de massa, capazes de exponenciar essa mesma memória esportiva, irradiando-a para toda a sociedade e para todo o mundo. A interface entre a "mídia e os discursos da memória", para falar com Andreas Huyssens (2004), torna a ferramenta rememorativa a um só tempo massiva e segmentada, uma vez que depende não exclusivamente da vontade dos indivíduos e atua de forma a reiterar aspectos do passado através de um repertório de informações e de imagens comuns.

Forjam-se por meio da imprensa as condições para a elaboração no século XX de uma "comunidade imaginada", termo consagrado por Benedict Anderson, em seu estudo a respeito da difusão do nacionalismo em países não-centrais, em um movimento de descentramento epistêmico e de crítica ao modelo explicativo etnocêntrico. Desta forma, embora o autor não trate do tema esportes em particular, pode-se afirmar que a memória esportiva coaduna-se à conformação da memória e da identidade nacionais nos países do assim chamado Sul Global.

Feitas as considerações de ordem mais abstrato-conceituais, vamos a seguir abordar como foi tratada a construção/conservação da memória olímpica no caso específico em questão. Para tanto, recorreremos a uma série de ações interinstitucionais, com início pelo programa geral de pesquisa acerca dos Jogos Olímpicos, seguido pelo subprojeto específico de História Oral voltado ao depoimento dos principais atores envolvidos e, last but not least, concluiremos com o conteúdo da exposição "Rio de Janeiro: cidade esportiva, cidade olímpica", todas elas atividades desenvolvidas nos quadros da Fundação Casa de Rui Barbosa, ao longo do ano de 2016. 
Dossiê | Memória olímpica como legado? A Fundação Casa de Rui Barbosa e seu projeto institucional de preservação da memória das Olimpíadas Rio 2016 (HOLLANDA, Bernardo Buarque de; FONSECA, Vivian Luiz)

Entre processos e ações: a preservação da memória dos Jogos Olímpicos Rio 2016 na Fundação Casa de Rui Barbosa

Nesta seção, vamos abordar uma ampla gama de ações coordenadas por uma instituição pública no sentido de salvaguardar a memória olímpica. $\mathrm{O}$ acesso a fontes primárias e a documentos internos, favorecido pela participação dos próprios autores deste artigo no projeto em tela, permite-nos apresentar o escopo geral da proposta.

Em abril de 2016, a Casa de Rui Barbosa, órgão sediado na zona sul do Rio de Janeiro e vinculado ao então Ministério da Cultura ${ }^{5}$, lançou um edital para 22 bolsistas atuarem no âmbito do projeto "Preservação da Memória das Olimpíadas: processos e ações". Sob coordenação geral da historiadora Lia Calabre, a chamada referia-se à produção de um conjunto documental amplo, com vistas ao registro da realização dos Jogos Olímpicos e Paralímpicos na cidade do Rio. Sendo o evento previsto para agosto daquele ano, estava-se, pois, a quatro meses do início do torneio internacional.

Neste momento foi estabelecida uma parceria com a Escola de Ciências Sociais CPDOC da Fundação Getulio Vargas, contando com a colaboração da autora deste artigo. Deve-se apontar que em paralelo ao início do desenvolvimento do projeto em questão, a FCRB ${ }^{6}$ e o FGV CPDOC realizavam em conjunto o "Ciclo de Filmes e Debates - As Olimpíadas vão ao cinema", coordenado pelos pesquisadores Antônio Herculano Lopes e Bernardo Borges Buarque de Hollanda. Assim, cumpre salientar a cooperação que vinha se firmando entre as duas instituições. Além destas duas iniciativas, a Casa de Rui Barbosa desenvolveu ainda outros seminários, como as palestras da série Educação e Esporte; e edição especial do ciclo História e Culturas Urbanas: "Rio olímpico, Rio dos esportes".

O projeto "Memória das Olimpíadas", assim como as demais atividades supracitadas, são fruto da provocação realizada pelo MinC na gestão do Ministro Juca Ferreira que, em 2015, iniciava uma série de estudos técnicos voltados para a compreensão do lugar da cultura nos Jogos Rio 2016 (CALABRE, 2017). Além da chancela

\footnotetext{
${ }^{5} \mathrm{O}$ MinC foi extinto, pela segunda vez, pelo presidente Jair Bolsonaro, ao tomar posse, em janeiro de 2019, reduzindo seu status à condição de secretaria especial do Ministério do Turismo. A primeira vez que isto aconteceu, com o rebaixamento da condição ministerial autônoma, fora durante o governo de Fernando Collor de Mello, em 1990.

${ }^{6}$ Doravante, acrônimo para Fundação Casa de Rui Barbosa.
} 
Dossiê | Memória olímpica como legado? A Fundação Casa de Rui Barbosa e seu projeto institucional de preservação da memória das Olimpíadas Rio 2016 (HOLLANDA, Bernardo Buarque de; FONSECA, Vivian Luiz)

do MinC, a proposta esteava-se em parceria acordada com a Autoridade Pública Olímpica (AOP) - instituição pública criada em 2011, num consórcio interfederativo a reunir as três esferas de governo - e, mais à frente, como já mencionado, com o CPDOC.

Em sua idealização, o projeto em tela estrutura-se em três pilares fundamentais esporte, cultura e cidade - e apresenta o objetivo de preservar memória da cidade olímpica, bem como produzir análises sobre o impacto dos Jogos para a sua cidade-sede e para o país anfitrião como um todo. O propósito era detalhado de modo a reunir, sistematizar e produzir informações, imagens, documentos e registros orais capazes de servir de base a futuros pesquisadores, com a criação de uma fonte abalizada para estudos e por intermédio de um portal de acesso específico. Esse site foi lançado em 2017 e encontra-se sediado no servidor da FCRB ${ }^{7}$.

A motivação para a iniciativa decorria, por suposto, do caráter único e extraordinário da edição no Brasil, com o entendimento de que o mesmo transpunha seu significado esportivo e transladava-se para as esferas da política, da sociedade, do marketing, do turismo e da economia da cultura. Uma segunda motivação importante era o diagnóstico de que boa parte da documentação e conhecimento sobre os Jogos Panamericanos 2007 e sobre a Copa do Mundo FIFA de Futebol 2014 estava dispersa e/ou inviável de ser acessada, dificultando novas pesquisas. Desse modo, o projeto buscava ser um meio de preservação da memória olímpica, mas igualmente, de parte da memória dos demais megaeventos esportivos realizados anteriormente. As mais de duas dezenas de bolsas visavam a constituição de uma equipe que, durante seis meses, dedicar-se-ia à composição desse acervo ${ }^{8}$. A seleção contemplava diferentes hierarquias acadêmicas, indo de iniciação científica a doutores, e de ciências humanas à área de tecnologia da informação (TIC). A esse conjunto de bolsistas somaram-se os pesquisadores da Casa de Rui Barbosa, Lia Calabre, coordenadora, Eula Cabral e Maurício Siqueira. E, do CPDOC, Vivian Fonseca, assim como a equipe do Programa de História Oral, notadamente Ninna Carneiro, que gravou a maior parte dos depoimentos realizados, e Vanessa Cavalcante, que treinou parte da equipe da FCRB. A equipe do Núcleo de Audiovisual e Documentário (NAD/CPDOC) também se somou ao grupo nos

\footnotetext{
${ }^{7}$ Cf. http://memoriadasolimpiadas.rb.gov.br/ Acesso em 15 de maio de 2020.

${ }^{8}$ Parte da equipe continuou atuando no projeto nos primeiros meses de 2007 buscando o aprimoramento do repositório.
} 
Dossiê | Memória olímpica como legado? A Fundação Casa de Rui Barbosa e seu projeto institucional de preservação da memória das Olimpíadas Rio 2016 (HOLLANDA, Bernardo Buarque de; FONSECA, Vivian Luiz)

ajudando no processo de edição e divulgação das entrevistas. Logo, na prática, cerca de 35 pessoas atuaram diretamente na estruturação desse Acervo.

O delineamento do projeto, que será iniciado concretamente em junho e concluído em meados de 2017, elencava seis finalidades principais, quais sejam:

1. Levantamento histórico do processo de viabilização dos Jogos Rio 2016, com a utilização de uma linha do tempo capaz de identificar seus marcos fundamentais e seus momentos-chaves, em âmbito nacional e internacional; 2. Coleta de depoimentos orais por parte da equipe de pesquisa, com o amplo espectro de atores involucrados nas fases pré-Jogos e pós-Jogos, assim como durante as Olimpíadas propriamente ditas; 3. Criação de um banco de dados com vistas a aferir o potencial de impacto gerado pela competição para a cidade (infraestrutura, financiamento, patrocínio, ampliação do alcance entre as diferentes modalidades esportivas, entre outras variáveis); 4. Subsídio para produção de análise do impacto no âmbito cultural da cidade; 5 . Produção de indicadores atinentes ao campo de transformações das dinâmicas urbanas da cidade do Rio, com depoimentos dos atores sociais correspondentes; 6. Organização de um acervo audiovisual.

Os eixos da pesquisa, conforme acima exposto, diziam respeito a um triplo legado: esportivo, cultural e urbano. O ponto de partida para tanto era o documento matriz das Olimpíadas para o país, isto é, o dossiê de candidatura submetido pelo governo brasileiro ao COI, quando da apresentação de sua candidatura, ainda nos anos 2000. Recorde-se que o país já pleiteara sua participação em edições anteriores (2004 e 2012), mas lograria êxito apenas em 2016, quando do anúncio de sua vitória no congresso de Copenhagen, acontecido em 2009.

A pesquisa do grupo da FCRB procurou compreender os ajustes feitos entre o enunciado da "carta de intenções" do poder público na submissão do pleito à cidadesede e a subsequente concretização desses ideais. Para fins operacionais, as ambições no tocante à juventude e à educação, por exemplo, foram subsumidas nos demais eixos, principalmente no dedicado aos esportes, uma vez que a prática desportiva pode contemplar os dois elementos supracitados.

As atividades culturais receberam atenção em função da própria natureza institucional responsável pela pesquisa, a Casa de Rui Barbosa, instituição de guarda reconhecida por seus acervos literários e históricos e por sua atuação na área de 
Dossiê | Memória olímpica como legado? A Fundação Casa de Rui Barbosa e seu projeto institucional de preservação da memória das Olimpíadas Rio 2016 (HOLLANDA, Bernardo Buarque de; FONSECA, Vivian Luiz)

políticas culturais. Seu interesse também decorre dos investimentos orçamentários empreendidos seja pela Presidência da República, seja pela Prefeitura do Rio de Janeiro.

Deve-se pontuar que diferente do que se imagina no senso comum, o 'componente cultural' esteve presente desde os primórdios dos Jogos Olímpicos e, mais recentemente, percebemos a importância dada pelo COI para a realização de festivais, shows, exposições, além de uma série de outras atividades em geral articuladas ao guarda-chuva cultura. Em linhas gerais, nessa perspectiva, esses eventos e atividades cumpririam a função de 'aquecer' a cidade para a realização dos Jogos, além de criar um clima e um engajamento da população e dos turistas em relação à temática.

Não obstante, diversas atividades culturais planejadas para a edição Rio 2016 não foram concretizadas, apesar do tema ter ganhado cada vez mais espaço na mídia. Funcionou, principalmente, a experiência do boulevard olímpico, na zona portuária da cidade (CARNEIRO, 2020). No eixo cidade, uma ênfase foi dada então ao investimento financeiro, tecnológico e de infraestrutura no porto do Rio de Janeiro, com a revalorização não só do patrimônio edificado como de seu repertório cultural, a exemplo do Museu do Amanhã.

Por suposto, trata-se de eixo transversal, posto que dialoga diretamente com o perímetro central da cidade e com a intervenção no meio urbano, com o objetivo de dinamizar os equipamentos culturais e o fomento turístico. O Rio também teve de preparar-se para formular políticas públicas de direito à cidade, em especial no quesito acessibilidade, porquanto o evento abrangia igualmente a recepção aos Jogos Paralímpicos e aos atletas portadores de necessidades especiais.

Por último, mas não menos importante, a fonte primária que consultamos da FCRB, datada de abril de 2016, lista os 6 produtos almejados e resultantes do projeto ao fim dos meses de pesquisa, a saber:

A. Produção de um site, para fazer as vezes de repositório responsável pelo armazenamento do material pesquisado. Junto ao conteúdo levantado pela pesquisa nos três eixos apontados, que reuniu em janeiro de 2017 mais de três mil itens, o portal apresentaria ainda dados obtidos pela Autoridade Pública Olímpica e pelas demais entidades envolvidas, o que acabou não se concretizando; B. Depoimentos orais produzidos por parte da equipe de pesquisadores nas três etapas dos Jogos (antes; durante; e depois), com alternância entre testemunhos breves, editados em 2 minutos 
Dossiê | Memória olímpica como legado? A Fundação Casa de Rui Barbosa e seu projeto institucional de preservação da memória das Olimpíadas Rio 2016 (HOLLANDA, Bernardo Buarque de; FONSECA, Vivian Luiz)

para divulgação, e entrevistas de maior duração, disponibilizadas na íntegra; C. Pesquisa de registro de memória, com o levantamento de todo o processo de organização das Olimpíadas no Brasil, compulsando notícias da imprensa e documentos oficiais; D. Seminário público com estudiosos e especialistas, a partir do qual se organizará um livro, em dois volumes, a reunir as contribuições apresentadas naquela ocasião; E. Exposição virtual no site referido no item $A$; F. Produto audiovisual que resulte na edição de um filme para exibição e divulgação.

\section{Vicissitudes da memória do "tempo presente": a criação de um projeto de História Oral para as Olimpíadas em 2016}

Uma vez apresentada a concepção geral do programa de atividades da FCRB, vamos avaliar um processo específico dessa frente de ações institucionais formulada em 2016. Em função da sua importância constitutiva para o terreno da memória olímpica, trataremos dos desafios metodológicos de construção do acervo de História Oral, desenvolvido pela FCRB e pelo FGV CPDOC nesse período (FONSECA; SIQUEIRA, 2017).

O banco de entrevistas em História Oral teve início efetivo em 1ำ de agosto de 2016 e contemplou uma diversidade de atores sociais, partícipes em determinada posição na organização e no desempenho das competições olímpicas, seja na condição de autoridades, de gestores, de técnicos e consultores. As gravações aconteceram em paralelo às outras frentes de ação das equipes, concentrando-se na meta principal do eixo "memória", sob coordenação de Carla Siqueira e Vivian Fonseca, com apoio de 7 pesquisadores e 2 bolsistas de iniciação científica 9 .

Seu método é preestabelecido: de início, a preparação das gravações envolve um processo de pesquisa em torno de assuntos e temas referentes aos Jogos. Na mesma proporção, as entrevistas filmadas - aptas a captar tanto a fala quanto a performance gestual do depoente - requerem um investimento acerca dos possíveis nomes a serem selecionados, com dados que subsidiem o roteiro de perguntas e as principais questões

\footnotetext{
${ }^{9}$ Os pesquisadores-bolsistas foram Ana Cristina C. de L. e Silva, Lilian Lustosa, Aparecida dos Santos Merces, Fernanda Raquel Abreu Silva, Leonardo Magalhães Firmino, Lucas Pacheco Campos e Tatiana Di Sabbato. As duas bolsistas de iniciação científica foram Cícera Vieira e Marina Martinez.
} 
Dossiê | Memória olímpica como legado? A Fundação Casa de Rui Barbosa e seu projeto institucional de preservação da memória das Olimpíadas Rio 2016 (HOLLANDA, Bernardo Buarque de; FONSECA, Vivian Luiz)

norteadoras dos depoimentos. À luz da metodologia consagrada pelo CPDOC/FGV desde os anos 1970, optou-se por uma história oral temática.

Não obstante, enfatizou-se que a natureza temática das entrevistas requeridas pelo Projeto não prescindiu da abordagem da história de vida dos selecionados para gravar. Deste modo, investiu-se ainda em informações sobre a trajetória e sobre os eventuais apontamentos biográficos dos entrevistados. A mediação no acesso e no contato com os depoentes foi favorecida graças à colaboração institucional da Autoridade Pública Olímpica (APO), como já frisado, entidade parceira da FCRB ${ }^{10}$.

Os critérios de escolha dos depoimentos em formato audiovisual - um incremento tecnológico com implicações para a interface entrevistador/entrevistado - são reveladores dos conteúdos levantados. Mencionem-se, por exemplo, as entrevistas com Sandra Maria e Dona Penha na Vila Autódromo - região da zona oeste do Rio afetada pelas obras para o evento -, que em novembro de 2016 falaram de suas ações junto ao Museu das Remoções. Este procurou ser um marco crítico do modo como moradores de comunidades situadas em espaços circunvizinhos da cidade olímpica foram oprimidos, expulsos e/ou prejudicados de alguma forma com as intervenções urbanísticas das Olimpíadas (Magalhães, 2013), desconhecendo qualquer tipo de "legado" a seu favor.

A formulação do subprojeto previu entrevistas que, ao final, estariam acessíveis pela Internet, com duração que varia de $1 \mathrm{~h}$ a $2 \mathrm{~h} 30$ e blocos temáticos com duração de 10 a 15 minutos. Apensas ao vídeo, de acordo com as normas de catalogação, seguemse a ficha técnica, a transcrição integral da entrevista e uma breve biografia do entrevistado, como pode ser visto na imagem abaixo ${ }^{11}$. O processo de tratamento das entrevistas foi supervisionado pelo Programa de História Oral e, as edições do material audiovisual ficaram sob responsabilidade do Núcleo de Audiovisual e Documentário, ambos do CPDOC.

\footnotetext{
${ }^{10}$ Cabe frisar a importante colaboração da pesquisadora Juliana Carneiro, professora da Universidade Federal Fluminense e, à época, Diretora de Operações e Serviços da Autoridade Pública Olímpica.

${ }^{11} \mathrm{O}$ repositório, assim como parte do acervo de entrevistas de história oral, os livros, seminários e demais produções do projeto estão disponíveis no link: http://memoriadasolimpiadas.rb.gov.br/. Na imagem destacada, o material das entrevistas de história oral realizadas com Marcelo Pedroso, Presidente Interino da APO à época de realização dos Jogos Rio 2016. Acesso em 15 de maio de 2020.
} 


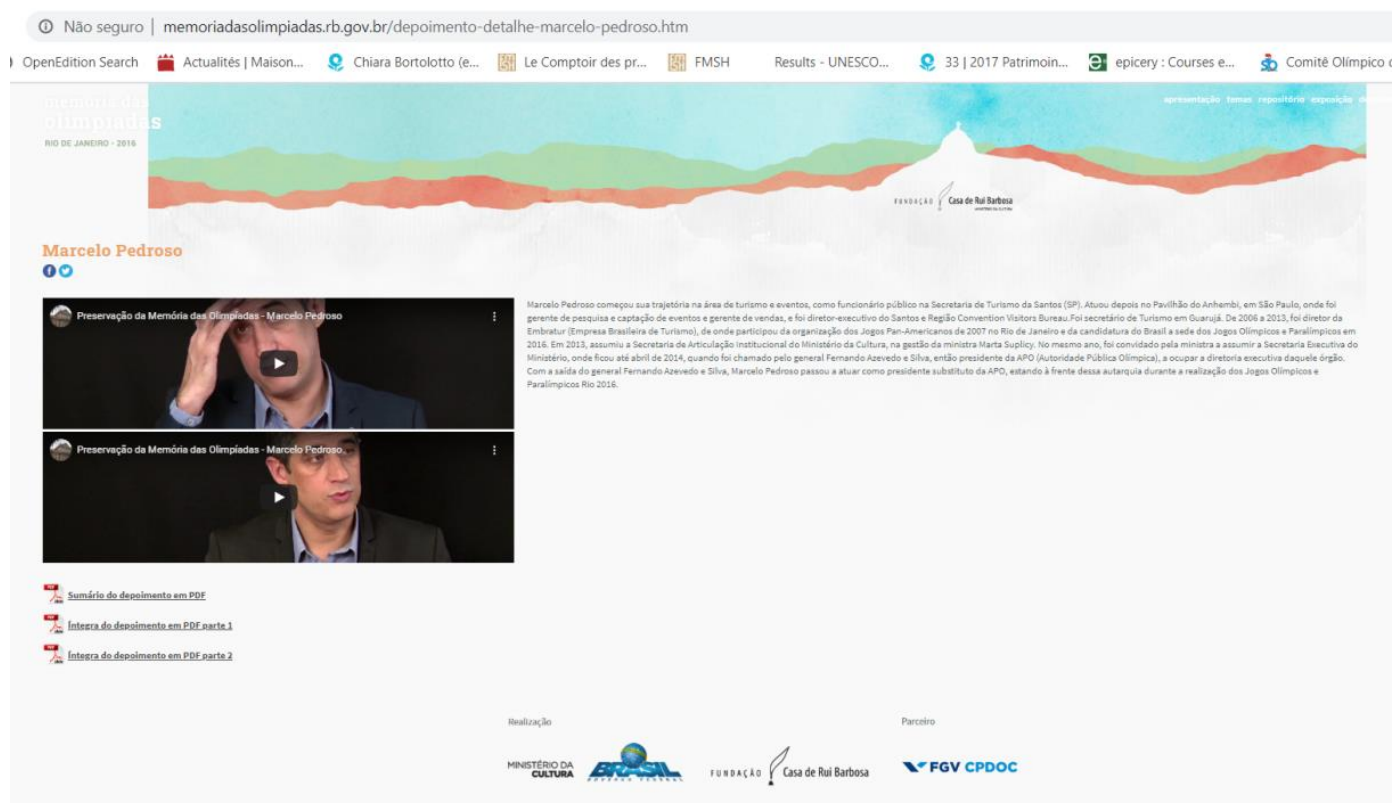

É importante destacar que, em função de constrangimentos orçamentários e também de prazo, nem todas as entrevistas foram editadas e constam no site. Há, ainda, os depoimentos que não poderiam ser disponibilizados em parte ou na íntegra em função de pedidos dos entrevistados ou pela falta de assinatura na Carta de Cessão de Direitos de Depoimento Audiovisual, documento utilizado pelo CPDOC e posteriormente também adotado pela FCRB. Algumas entrevistas foram realizadas após a data final de encerramento do projeto, inviabilizando a inclusão no site oficial. Neste caso encontram-se as entrevistas com Carla Camurati e Eduardo Paes, por exemplo.

Buscando maior capacidade de difusão e de preservação desses documentos audiovisuais, todas as entrevistas apresentam duplo depósito, ou seja, estão arquivadas tanto na FCRB quanto no CPDOC. Igualmente buscando maior difusão da pesquisa e experimentos com outras linguagens, foi realizado o documentário Por trás dos Jogos, a candidatura ${ }^{12}$, sobre o processo de construção da candidatura olímpica brasileira.

Voltando ao acervo de história oral, encontramos cerca de 45 sessões com 30 atores sociais, totalizando aproximadamente $100 \mathrm{~h}$ de gravação no formato audiovisual. Nesse escopo, temos lideranças de movimentos sociais críticas à realização dos Jogos, políticos e quadros técnicos de diferentes entes federativos, membros dos Comitês Olímpico e Paralímpico brasileiros, consultores e, também, do Comitê Organizador Rio

\footnotetext{
12 Documentário produzido conjuntamente pela FCRB e pelo FGV CPDOC, Rio de Janeiro, 2017, 21'34". Disponível em: http://memoriadasolimpiadas.rb.gov.br/ Acesso 15 de maio de 2020.
} 
Dossiê | Memória olímpica como legado? A Fundação Casa de Rui Barbosa e seu projeto institucional de preservação da memória das Olimpíadas Rio 2016 (HOLLANDA, Bernardo Buarque de; FONSECA, Vivian Luiz)

2016. Em suma, procurou-se ter um registro o mais amplo possível do processo de candidatura, desenho, organização, preparação, realização e desmontagem dos Jogos. No entanto, atletas e seus treinadores, em geral foco de projetos de memória olímpica, não constavam em nosso escopo de entrevistados em função do desenho de projeto desenvolvido.

Um dos aspectos que deve ser pontuado é a dificuldade inerente a uma empreitada deste porte, tendo em vista o amplo aspecto de temáticas associadas à realização deste megaevento. Para além de questões relacionadas ao esporte, encontramos os temas da infraestrutura urbana, transportes, energia, segurança, governança, diplomacia, políticas públicas, equipamentos esportivos, movimentos sociais, programação cultural, entre diversas outras. Por fim, conforme pontuam Fonseca e Siqueira (2007:71), as entrevistas de história oral buscaram e possibilitam acesso a "informações que não estão disponíveis em outros tipos de documentação", pois essas fontes:

... trazem detalhes dos processos decisórios e dos bastidores da produção do evento. Além disso, revelam também a constituição de um know-how de organização de megaeventos esportivos no Brasil, que vem desde os Jogos Pan-Americanos e Parapan-Americanos de 2007, também realizados no Rio de Janeiro. $O$ processo de governança, que inicialmente não nos despertava tanto interesse, meses depois nos é evidente a sua destacada importância como objeto que merece grande atenção nas entrevistas.

Um dos aspectos metodológicos a ser frisado é que a História Oral desenvolvida para esse projeto foi feita no próprio contexto de preparação, de realização, de imediata sucessão dos Jogos e, ainda, tivemos algumas entrevistas realizadas em 2017, 2018 e $2019^{13}$. Ou seja, os registros orais captam a conjuntura em que o torneio foi realizado, com todas as vicissitudes e questões de fundo que rodeiam sua efetivação. Logo, o tipo de relato que se colhe está colado ao próprio fato que se analisa, sem o distanciamento temporal muitas vezes esperado nesse tipo de empreitada (FONSECA; SIQUEIRA, 2017). Como todo o processo seletivo, a proximidade e a distância são escolhas e acarretam implicações positivas e negativas, com perdas e ganhos inerentes à decisão. Cabe ainda

\footnotetext{
${ }^{13}$ As entrevistas realizadas a partir de 2018 encontram-se depositadas unicamente no FGV CPDOC.
} 
Dossiê | Memória olímpica como legado? A Fundação Casa de Rui Barbosa e seu projeto institucional de preservação da memória das Olimpíadas Rio 2016 (HOLLANDA, Bernardo Buarque de; FONSECA, Vivian Luiz)

pontuar o cenário no qual o projeto foi desenvolvido: de aguda crise política brasileira, seguida de uma crise econômica, ambas presentes até o momento. 2016 foi marcado pelo processo de impeachment da Presidenta Dilma Rousseff e subida à Presidência da República de seu Vice-presidente, Michel Temer. No 'ano olímpico' também foram realizadas as eleições municipais no Brasil, o que tomou grande parte da energia e do tempo de nossos entrevistados.

Não vale desta forma julgar. Cabe, isto sim, ter a consciência das circunstâncias em que a fonte foi criada, para que se tenham parâmetros analíticos quando o material vier a ser analisado por um pesquisador no futuro.

\section{Uma imagem da cidade pelos esportes: notas sobre a exposição "Rio de Janeiro - cidade esportiva, cidade olímpica"}

Em setembro de 2016, ainda durante a ambiência dos Jogos - as disputas Paralímpicas acontecem naquele mês -, a Casa de Rui Barbosa inaugura uma exposição em um de seus saguões principais. O mote da exposição é exibir textos e imagens da história das primeiras edições dos Jogos Olímpicos, entre 1896 e 1948, tal como reportados pela imprensa da época e tal como vivenciados na cidade do Rio de Janeiro do período. Explora-se, mais especificamente, a participação brasileira a partir de 1920, quando uma delegação representa o país na Antuérpia, Bélgica, logo após a Grande Guerra (1914-1918).

Além de coadunar-se à frente coletiva institucional de preservação da memória na FCRB, a exposição tem por objetivo secundário valorizar e divulgar seu acervo de periódicos, revelando conteúdos sobre a cidade e sobre os esportes.

O princípio curatorial era claro e coerente. Aqui também, partia-se do pressuposto de que a realização dos Jogos Olímpicos no Rio de Janeiro era um feito inédito e extraordinário, e que, em exatos 120 anos de história, entre 1896 e 2016, era a primeira vez que a moderna versão desse que hoje é um dos maiores megaeventos esportivos internacionais realizava-se em uma cidade da América do Sul.

A curadoria salientava ademais que as características geográficas, históricas e sociais do Rio, marcadas por sua história portuária e por sua centralidade políticocultural na formação do Brasil, tornavam-se alvo de interesse de milhares de turistas, 
Dossiê | Memória olímpica como legado? A Fundação Casa de Rui Barbosa e seu projeto institucional de preservação da memória das Olimpíadas Rio 2016 (HOLLANDA, Bernardo Buarque de; FONSECA, Vivian Luiz)

nacionais e estrangeiros, à espera de sua afluência à cidade. Visitantes de todo o mundo teriam a oportunidade de assistir às diversas modalidades, desempenhadas por atletas de seus países, e de presenciar as mais diferentes competições desse rito quadrienal do "concerto das nações" que são as Olimpíadas.

O feito, memorável na vida do país, tinha por significado extrapolar os dezoito dias de atividades competitivas e de performances atléticas acontecidas ao longo do mês anterior. Assim como as expectativas que antecederam os últimos sete anos de preparação, desde que a cidade foi eleita para sediar dos Jogos em 2009, na Dinamarca, a exposição sobre o torneio ensejava a reflexão em torno de questões fundamentais: Que cidade se queria? Como os esportes contribuíam para pensar a esfera pública de um país? Qual a utilidade dos novos espaços para a integração social? Que legado deixariam os equipamentos esportivos para a mobilidade urbana?

O evento, sublinhava a exposição, despertava também um olhar retrospectivo, uma espécie de busca pelas nossas raízes esportivas. Estas se traduzem em uma curiosidade pelo passado, isto é, em atenção ao processo de constituição do Rio como locus para atividades físicas e atléticas. Desde seu aparecimento, as práticas corporais vinham sendo cultivadas nos espaços fechados dos ginásios, dos estádios e dos clubes, mas também nos ambientes aerados das praias e das ruas, dos morros e dos parques (MELO, 2001).

Uma das dimensões acionadas pela memória coletiva da exposição dizia respeito à história das práticas desportivas. O caráter especial do acontecimento movia em direção às suas origens, de modo a entender a maneira pela qual o hábito de praticar esportes foi construído no espaço urbano no decorrer do século XX. É assim que o interesse nos Jogos remetia ao tempo pregresso, no afã de compreender como uma cidade moderna tornava-se uma cidade esportiva e como esta, por seu turno, convertiase pela primeira vez em cidade olímpica.

A exposição procurou então ser uma pequena amostra dos primórdios esportivos da cidade, convertida em palco esportivo do mundo. Trata-se de uma breve incursão pelas fontes do primeiro tempo do imaginário esportivo nacional, uma vez que, segundo dizia o sociólogo Gilberto Freyre, o Rio de Janeiro era uma cidade "panbrasileira". A fim de animar esta história, a exposição reúne imagens de um dos acervos mais caros à Fundação Casa de Rui Barbosa: as revistas semanais ilustradas. 
Dossiê | Memória olímpica como legado? A Fundação Casa de Rui Barbosa e seu projeto institucional de preservação da memória das Olimpíadas Rio 2016 (HOLLANDA, Bernardo Buarque de; FONSECA, Vivian Luiz)

Revistas ilustradas foram periódicos surgidos na capital da República em princípios do século XX. O Malho, Fon Fon e Careta constituíram alguns dos seus mais representativos semanários. Eles marcaram época, quer seja pela irreverência de seu humor político, pela crítica social de suas reportagens ou pela projeção de seus artistasprofissionais, responsáveis por importantes inovações no campo do jornalismo brasileiro.

Tais revistas representaram um marco na esfera das artes gráficas e projetaram caricaturistas do porte de J. Carlos, Di Cavalcanti, Calixto Cordeiro, Raul Pederneiras, Alfredo Storni, Francisco Romano, Arnaldo Branco, entre tantos outros. A inventividade das capas, aliada ao caráter subversivo do riso e ao traçado inovador de charges, caricaturas e pinturas, estendeu-se também ao estilo incomum da linguagem jornalística, ao jogo metalinguístico de alguns números e ao conteúdo inusitado dos fait divers ali reportados.

Em razão do padrão alcançado no design e no texto, esses periódicos assistiram a um notável sucesso de vendas na primeira metade do século XX. Pode-se dizer que tiveram vida longa, se comparados às efêmeras publicações da época, e são ainda hoje preciosos documentos que registram parte expressiva do cotidiano da vida republicana brasileira.

A escolha das fontes relaciona-se igualmente à temática que guia esta exposição. A existência de tais revistas coincide com o período de surgimento, afirmação e consolidação de diversas modalidades esportivas no Brasil. Historicamente, tais modalidades foram trazidas da Europa e da América do Norte, sobretudo da GrãBretanha, a grande responsável pela codificação e pela difusão da maioria dos esportes modernos na contemporaneidade. Em um curto espaço de tempo, popularizaram-se também no país, sendo o Rio de Janeiro uma de suas principais portas de entrada.

As imagens fotográficas, os desenhos e os textos selecionados na exposição procuram, pois, ser uma mostra da miríade de práticas que galvanizaram o habitante da cidade nas primeiras décadas do século XX. Procura-se mostrar de igual maneira a repercussão crescente na imprensa dessa que foi chamada de "febre esportiva", com a sua disseminação pelas múltiplas áreas que compunham o perímetro urbano do então Distrito Federal. 
Dossiê | Memória olímpica como legado? A Fundação Casa de Rui Barbosa e seu projeto institucional de preservação da memória das Olimpíadas Rio 2016 (HOLLANDA, Bernardo Buarque de; FONSECA, Vivian Luiz)

As fotos, as charges e as matérias das revistas ilustradas exibidas - iremos a seguir reproduzir algumas delas - permitem perceber a constituição de um campo esportivo, que se estrutura e se organiza ao redor dos seus protagonistas principais, os sportmen, personagem-símbolo da belle époque tropical, mas também dos prados e dos hipódromos, das pistas e das piscinas, dos campos e das enseadas, dos velódromos e dos autódromos, espaços que demarcam os territórios próprios aos esportes modernos.

Tais práticas, por sua vez, formam-se a partir de um público inicialmente apenas curioso, mas progressivamente interessado e engajado. Composta tanto por homens quanto por mulheres, a "assistência", como então se denominava nos jornais, fazia do esporte uma atividade social, ao mesmo tempo lúdica e utilitária, capaz de promover entretenimento para os assistentes, desafio de superação para os competidores e bons negócios para os organizadores.

Com efeito, a "febre esportiva" transbordava suas fronteiras à medida que os espectadores dos espetáculos esportivos se mostravam mais e mais atraídos pelas competições, então divididas em dois tipos: aquáticos e terrestres. Uma das consequências desta atração foi a criação e a institucionalização de entidades nacionais, como a Confederação Brasileira de Desportos (CBD), incumbida da organização de torneios de dimensão internacional.

Outra consequência paulatina dessa popularização foi o estímulo ao estabelecimento de vínculos sociais de pertencimento coletivo por meio dos esportes. Isto foi potencializado através da identificação dos espectadores com um determinado desportista, com uma determinada equipe ou mesmo com uma específica agremiação clubística. De espectadores tornaram-se assim torcedores, vinculando-se afetivamente a um clube de sua predileção.

Para dar conta desse rico fenômeno, a exposição aposta em um duplo recorte: temporal e temático. O primeiro diz respeito à cronologia, que se inicia com reportagens do ano de 1918, quando os esportes já estão disseminados em diversos pontos da cidade e já se consolidaram no imaginário do país. A baliza cronológica se dilata até o ano de 1948, ocasião em que, terminada a Segunda Guerra mundial, os Jogos Olímpicos são restabelecidos. Com seu restabelecimento, o evento retoma o seu ciclo quadrienal e a participação brasileira, até então irregular, passa a ser cada vez mais constante e estruturada. 
Dossiê | Memória olímpica como legado? A Fundação Casa de Rui Barbosa e seu projeto institucional de preservação da memória das Olimpíadas Rio 2016 (HOLLANDA, Bernardo Buarque de; FONSECA, Vivian Luiz)

Quanto ao tema, o fio condutor da exposição estrutura-se em três partes: na primeira, estão as vitrines da sala principal, que apresentam os registros das múltiplas práticas associadas aos esportes no Rio de Janeiro de fins da década de 1910. São exemplos o atletismo, o críquete, a natação, o polo aquático, ciclismo, o tiro ao alvo, o tênis, a esgrima, o iatismo, o automobilismo, além de duas de duas modalidades populares e muito significativas: o turfe e o remo.

Em seguida, as vitrines do corredor lateral destacam a chamada footballmania, termo cunhado no início do século passado pelo sociólogo e educador Fernando de Azevedo. Enfoca-se o futebol com base em um ano preciso, o de 1919. Este é escolhido por representar o clímax da popularidade alcançada à época, quando da realização de um dos primeiros e maiores eventos esportivos de magnitude internacional ocorrido no Rio de Janeiro: o III Campeonato Sul-Americano.

Ao longo do mês de maio daquele ano, o torneio reuniu os selecionados do Brasil, do Uruguai, da Argentina e do Chile, em partidas disputadas no Estádio das Laranjeiras. No campo do Fluminense Football Club, uma multidão de fãs futebolísticos lotou as suas dependências a cada partida brasileira. Pode-se assim assistir à heroica conquista de um título continental, feito que despertou a comoção popular, entusiasmou a imprensa, paralisou a cidade e imortalizou um ídolo da fase amadora do nosso futebol: o mestiço Arthur Friedenreich, atacante do Clube Atlético Paulistano, autor do gol dramático que deu o título ao Brasil.

Por fim, os painéis da sala principal tematizam os momentos iniciais da participação de atletas brasileiros nos Jogos Olímpicos, na primeira metade do século XX. Apenas depois da Primeira Guerra mundial, com a sétima edição das Olimpíadas, em 1920, o país se vê representado pela primeira vez, participando das competições na Antuérpia. A cidade da Bélgica fora eleita para sediar os JO por constituir um símbolo da resistência durante o cerco bélico, em meio à luta perpetrada por tropas britânicas, belgas e francesas contra as forças alemãs, ainda no primeiro ano da guerra, em 1914. 


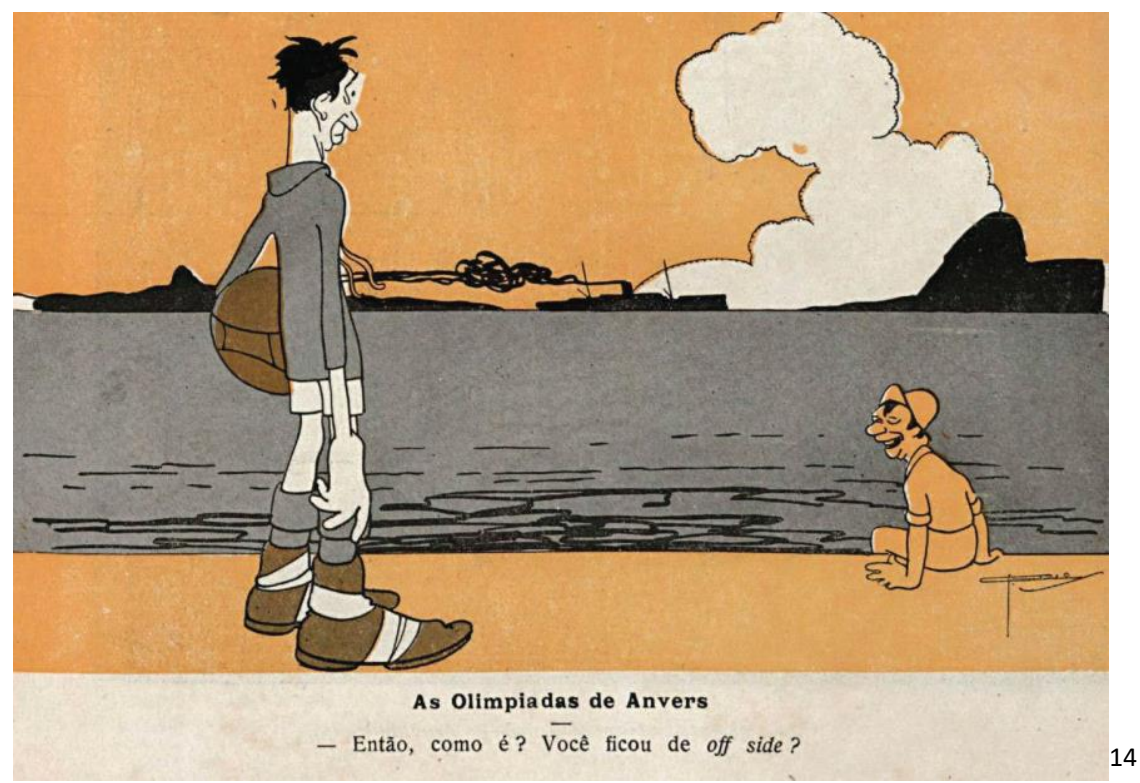

A charge de J. Carlos faz blague com futebolista brasileiro. Enquanto o navio Curvello, cedido pelo governo do Brasil à delegação olímpica, parte rumo a Portugal, primeira parada antes de chegar à cidade belga de Antuérpia, observador sentado alude, em tom jocoso, à não participação brasileira na modalidade futebolística durante a sexta edição das Olimpíadas (1920), a primeira depois da I Guerra Mundial (19141919).

Naquela edição dos Jogos, o Brasil comparece com uma delegação de vinte e dois atletas. Ao final, o país conquista, pela primeira vez, três medalhas na competição - uma de ouro, outra de prata e a terceira de bronze - graças às façanhas dos atiradores Guilherme Paraense, Afrânio da Costa, Sebastião Wolf, Dario Barbosa e Fernando Soledade.

${ }^{14}$ Futebol. Careta. 17.07.1920 
A proposito da victoria do tenente Paraense, proclamado campeão mundial do tiro de revólver:

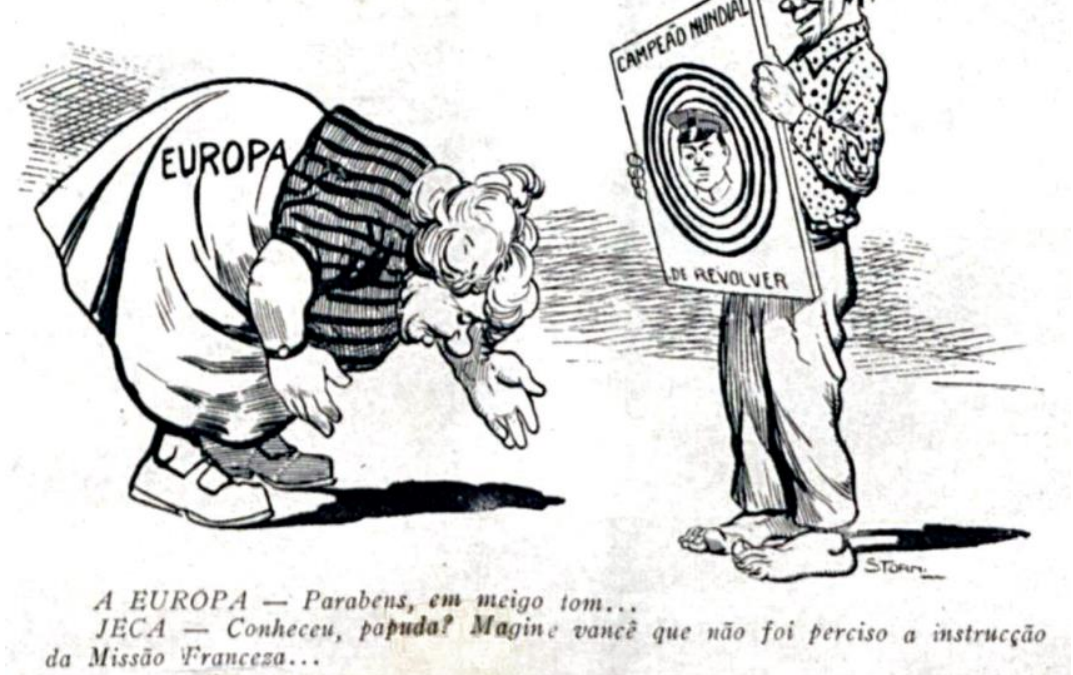

da Missão Franceza...

A reportagem acima tematiza a vitória brasileira na Bélgica. O caricaturista Alfredo Storni reabilita a figura prototípica do Jeca Tatu para ironizar a imagem da "Europa curvada ante o Brasil", mote cunhado pela imprensa em princípios do século XX e veiculado logo após a façanha do aviador Santos Dumont, que se tornou célebre internacionalmente por contornar a Torre Eiffel a bordo do seu dirigível

Quatro anos depois, nos Jogos Olímpicos de Paris, a presença nacional foi tímida, onze atletas e o desempenho pífio, devido a restrições orçamentárias que limitaram os representantes ao atletismo e ao remo. É neste sentido que o desenho abaixo, da Revista Careta, ironiza um espectador brasileiro que interpela o atleta conterrâneo, ante o "vexame internacional":

${ }^{15}$ Europa curvada. O Malho. 14.08.1920. 


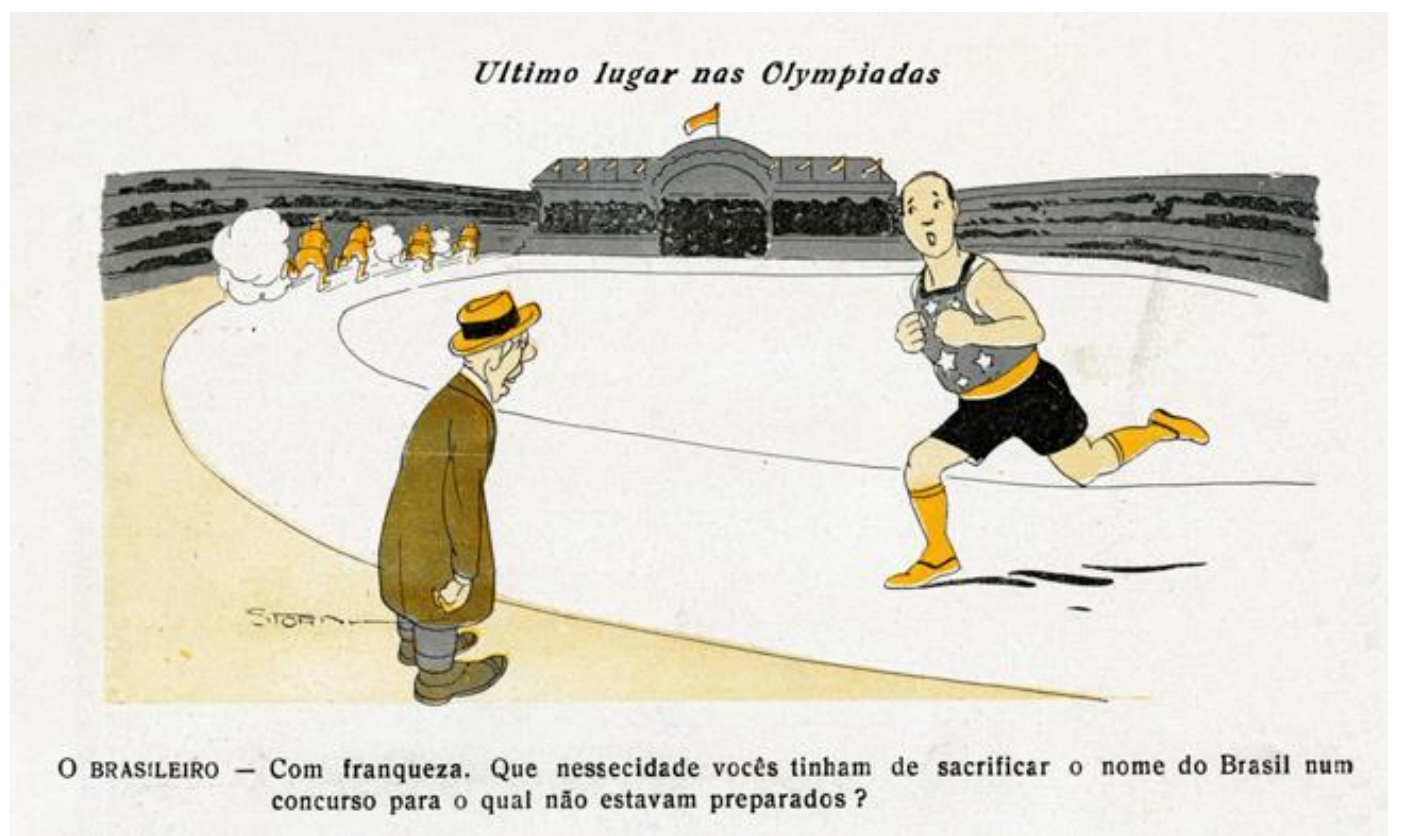

Em 1928, na capital holandesa, Amsterdã, o Brasil não pode participar, em razão da crise financeira por que passava o seu governo. Já nas Olimpíadas de 1932, em Los Angeles (EUA), o país volta a comparecer, desta vez com destaque para a nadadora Maria Lenk, a primeira mulher brasileira a tomar parte do evento. $O$ feito suscita de $O$ Malho uma capa jocosa, a contrastar a baixa estatura do presidente da República do Brasil diante do "todo poderoso" Tio Sam, caricatura do estadunidense:

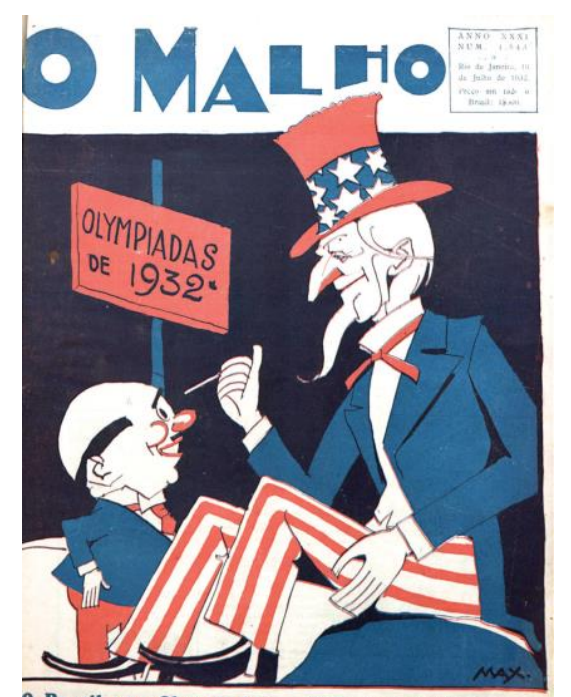

0 Brasil nas Olympiadas - asom

\footnotetext{
${ }^{16}$ Tio Sam. O Malho. 16.07.1932 - Sugestiva caricatura do presidente da República Getúlio Vargas diante do Tio Sam, em alusão ao início das Olimpíadas de Verão em Los Angeles, no ano de 1932.
} 
Dossiê | Memória olímpica como legado? A Fundação Casa de Rui Barbosa e seu projeto institucional de preservação da memória das Olimpíadas Rio 2016 (HOLLANDA, Bernardo Buarque de; FONSECA, Vivian Luiz)

Ainda que pouco expressiva em termos quantitativos, a delegação do país faz-se presente em 1936, durante os Jogos Olímpicos de Berlim, com a presença do então nadador João Havelange. Em 1948, após doze anos de interrupção do torneio, em função de novos conflitos bélicos internacionais, o Brasil retoma sua participação nas Olimpíadas. Envia assim atletas a Londres, cidade-sede escolhida por ser um dos bastiões da resistência antifascista durante a Segunda Guerra mundial. Na capital londrina, o Brasil é representado novamente por atletas que se sagram medalhistas. Desta feita, conquista-se o bronze no basquetebol masculino.

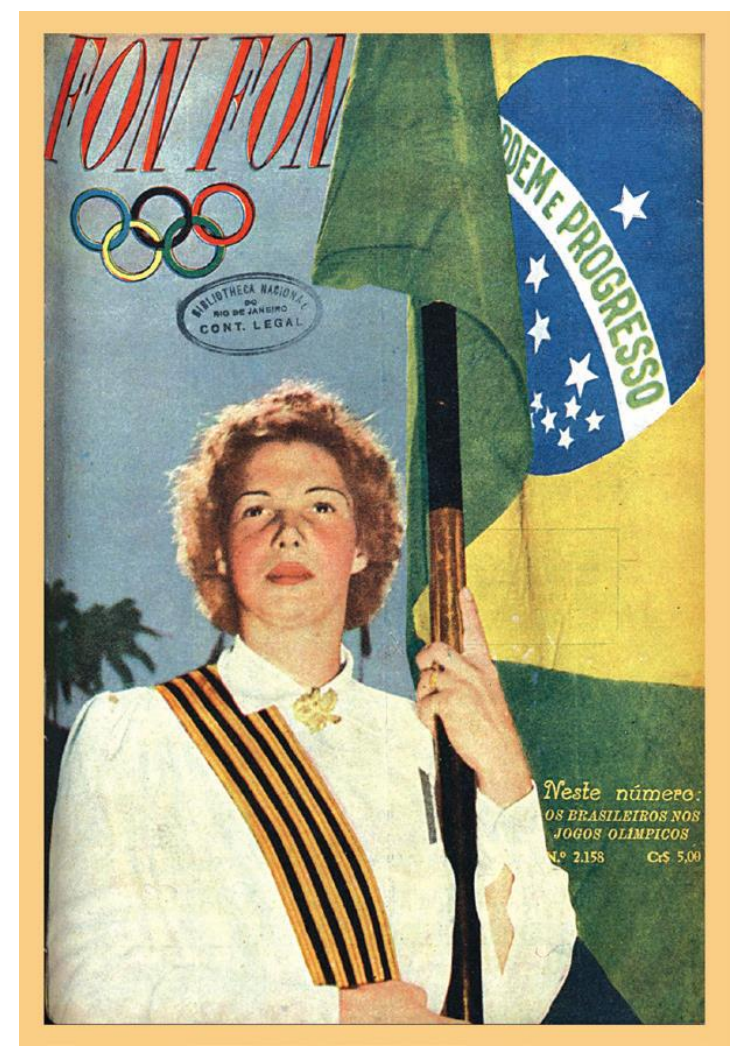

A última Olimpíada coberta pela exposição apresenta as edições de 1948, ocorridas em Londres, na esteira da Segunda Guerra mundial (1939-1945). Note-se a foto colorida da capa, expressão do aprimoramento técnico das revistas de então. A imagem capta a solenidade de abertura da Olimpíadas londrinas, em foto de autoria de Sasha Harnisch. A nadadora Piedade Coutinho (1920-1997), no desfile que dá início à competição, é a atleta da delegação brasileira que empunha bandeira do Brasil. 
Dossiê | Memória olímpica como legado? A Fundação Casa de Rui Barbosa e seu projeto institucional de preservação da memória das Olimpíadas Rio 2016 (HOLLANDA, Bernardo Buarque de; FONSECA, Vivian Luiz)

Piedade compôs a equipe de nadadoras que viajaram para representar o país ao lado de Maria Angélica, Thalita Rodrigues, Eleonora Schimitt e Edith Groba. No total, Piedade participou de três edições dos Jogos Olímpicos (Berlim, 1936; Londres, 1948; Helsinque, 1952), tendo treinado pelo Clube de Regatas Guanabara e pelo Clube de Regatas do Flamengo.

O recorte cronológico permite que a exposição abarque a cronologia da participação das delegações olímpicas brasileiras, entre 1920 e 1948. Para tanto, em contrapartida, valoriza ao mesmo tempo o repertório iconográfico e de conteúdo da Casa de Rui Barbosa, numa via de mão dupla entre a afirmação institucional e a proposição de um "lugar de memória" não só dos Jogos Rio 2016 como também da presença do país na história das edições do torneio internacional, em seus mais de 120 anos de existência.

\section{A título de conclusão}

Preservação: palavra de ordem nas últimas décadas, como bem pontuam diversos pesquisadores ao analisarem o cenário de obsessão memorial que tomou conta das sociedades ocidentais e ocidentalizadas (TRAVERSO, 2012). Não obstante, apesar dessa dimensão cada vez mais presente, percebemos um cenário oposto quando observamos os Jogos Pan-americanos 2007, assim como os demais megaeventos esportivos da chamada 'década' esportiva brasileira.

No tocante às Olimpíadas Rio 2016, procuramos salientar neste artigo um cenário distinto das críticas e dos questionamentos, ao mobilizar uma série de iniciativas realizadas no sentido de registrar e salvaguardar a experiência desse evento inédito vivenciado pela cidade, pelo país e pela América do Sul. Para tanto, emissoras de TV, universidades, museus e diversas outras instituições envidaram esforços no sentido de garantir a preservação de documentos e de memórias sobre esse momento.

Entre elas, cabe destacar o projeto Atletas Olímpicos brasileiros, da professora Katia Rubio (USP), que gerou livro homônimo publicado em 2015, com cerca de 1800 verbetes ${ }^{17}$. Ou ainda o Memória do Esporte Olímpico Brasileiro ${ }^{18}$, projeto que gerou 31

\footnotetext{
${ }^{17}$ http://www.olimpianos.com.br/AtlOlim.html Acesso em 20 de abril de 2020.

${ }^{18} \mathrm{https} / / /$ memoriadoesporte.org.br/ Acesso em 20 de abril de 2020.
} 
Dossiê | Memória olímpica como legado? A Fundação Casa de Rui Barbosa e seu projeto institucional de preservação da memória das Olimpíadas Rio 2016 (HOLLANDA, Bernardo Buarque de; FONSECA, Vivian Luiz)

documentários e foi realizado pelo Instituto de Políticas Relacionais, com patrocínio da Petrobras, do E-Brasil Energia e da ESPN Brasil, com apoio da Secretaria do Audiovisual do MinC e da Cinemateca Brasileira.

Malgrado esses projetos variados, houve a proposta (frustrada) dos órgãos públicos e do COB relacionados à organização e realização das Olimpíadas no Brasil. Estes, inicialmente, previam a criação de um museu que recuperasse, inclusive, os Jogos Pan-americanos Rio 2007, trazendo não apenas a documentação, como também memorabilia associada aos eventos do decênio. A documentação referente a esta efeméride mostra que, a despeito da questão ter entrado diversas vezes em pauta, não teve força política suficiente para se tornar uma agenda que comprometesse diversos atores e instituições. Manteve, afinal, o tópico como uma possibilidade distante, quase utópica. Desse modo, o conjunto de atividades realizado pela Fundação Casa de Rui Barbosa e, em especial, o projeto "Preservação da Memória das Olimpíadas: processos e ações", encontra lugar de destaque. Ele possibilita a realização de pesquisas futuras, assim como uma reflexão sobre como o país desenvolve programas de preservação de sua memória e de seus acervos. Esta última dimensão também foi favorecida por essa volta ao seu arquivo histórico, com base na exposição "Rio de Janeiro - cidade esportiva, cidade olímpica", que procuramos no presente texto destacar.

No mais, esse artigo buscou contribuir com uma reflexão sobre processos de construção memorial, procurando entendê-los também como frutos do seu tempo, marcados pelas vicissitudes, pelos constrangimentos e pelas questões que afligem seus pesquisadores no momento da sua feitura. Conforme já apontamos acima, tal dimensão deve ser apontada não para julgamentos, mas para a compreensão dos mecanismos institucional de produção de acervos, de desenvolvimento pesquisas e projetos, todos eles, por pressuposto, dotados igualmente de historicidade.

\section{Referências}

ANDERSON, Benedict. Comunidades imaginadas: reflexões sobre a origem e a difusão do nacionalismo. São Paulo: Companhia das Letras, 2008.

BENJAMIN, Walter. A obra de arte na era da sua reprodutibilidade técnica. Porto Alegre: LP\&M, 2018.

BOURDIEU, Pierre. Coisas ditas. São Paulo: Brasiliense, 1990. 
Dossiê | Memória olímpica como legado? A Fundação Casa de Rui Barbosa e seu projeto institucional de preservação da memória das Olimpíadas Rio 2016 (HOLLANDA, Bernardo Buarque de; FONSECA, Vivian Luiz)

CALABRE, Lia. "Prefácio". In: CALABRE, Lia; CABRAL, Eula Dantas; SIQUEIRA, Maurício; FONSECA, Vivian (Orgs.). Memória das Olimpíadas no Brasil: diálogos e olhares. Rio de Janeiro: Fundação Casa de Rui Barbosa, vol. 1, 2017.

CARNEIRO, Juliana. O lugar da cultura nos Jogos Olímpicos Rio 2016: uma análise comparativa entre o Dossiê de Candidatura e as Olimpíadas Culturais. Rio de Janeiro: Tese de doutorado em História Comparada, UFRJ, 2020.

DAMO, Arlei; OLIVEN, Rubem. "O Brasil no horizonte dos megaeventos esportivos de 2014 e 2016: sua cara, seus ócios e negócios". In: Revista Horizontes Antropológicos. Porto Alegre: vol. 19, n. 40, p. 19-63, 2013.

ELIAS, Norbert; DUNNING, Eric. Quest for excitement: sport and leisure in the civilizing process. Dublin: University College Dublin Press, 2008.

FONSECA, Vivian; SIQUEIRA, Carla. "Memória dos Jogos Rio 2016: desafios metodológicos na construção de um acervo de História Oral". In: CALABRE, Lia; CABRAL, Eula Dantas; SIQUEIRA, Maurício (Orgs.). Memória das Olimpíadas no Brasil: diálogos e olhares. Rio de Janeiro: Fundação Casa de Rui Barbosa, vol. 2, 2017.

HUYSSENS, Andreas. "Mídia e discursos da memória". In: Revista Brasileira de Ciências da Comunicação. São Paulo: Volume XXVII, n. 1, janeiro/junho, p. 97-106, 2004.

LE GOFF, Jacques. "Memória". In: Memória-história. Lisboa: Imprensa Nacional/Casa da Moeda, 1986.

LOWENTHAL, David. The past is a foreign country. Cambridge: University Press, 1985.

MAGALHÃES, Alexandre. “O 'legado' dos megaeventos esportivos: a reatualização da remoção de favelas no Rio de Janeiro". In: Revista Horizontes Antropológicos. Porto Alegre: vol. 19, n. 40, p. 89-118, 2013.

MELO, Victor Andrade de. Cidade sportiva: primórdios do esporte no Rio de Janeiro. Rio de Janeiro: Relume Dumará, 2001.

SEVCENKO, Nicolau. A corrida para o século XXI: no loop da montanha russa. São Paulo: Companhia das Letras, 2001.

SPAGGIARI, Enrico; MACHADO, Giancarlo; GIGLIO, Sérgio (Orgs.). Entre jogos e copas: reflexões de uma década esportiva. São Paulo: Intermeios, 2016.

TRAVERSO, Enzo. O passado, modos de usar. Lisboa: Unipop, 2012.

VELHO, Gilberto. “Memória, identidade e projeto”. In: Projeto e metamorfose. Rio de Janeiro: Zahar, 1994.

WEINRICH, Harald. Lete: arte e crítica do esquecimento. Rio de Janeiro: Civilização Brasileira, 2001.

YATES, Francis. A arte da memória. Campinas: Editora UNICAMP, 2007. 